from other former Soviet republics and is able to adapt to European standards.

It was because of the different political conditions that Ukraine was chosen by the author as a country that severed ties with Russia and other post-Soviet countries and gradually moved towards an alliance with Europe, Belarus, as a country that remains in close contact with Russia, and the Baltic states, which are part of the European Union and have completely different tax systems. The purpose of this article is to analyze the tax systems of Ukraine, Belarus and the Baltic countries, to study their specifics, common and distinctive features.

According to the analysis, a progressive tax system is more efficient in terms of economic functioning, improving living standards and satisfaction with living in the country. Despite the greater tax burden, the population of the Baltic States is more satisfied with the political and social spheres of life and the level of social security. A progressive tax system and benefits for certain activities (IT, investment, science development) can provide Ukraine with significant economic development, increased public confidence and, as a result, an increase in living standards in the country as a whole.

In further research, the author plans to analyze the tax systems of more developed countries and the possibility of adopting their experience in taxation, in particular in the introduction of progressive tax rates and benefits for certain types of business activities.

УДК 331.103

DOI: 10.35340/2308-104X.2021.91-2-15

\section{WELL-BEING-ЯК АДАПТАЦІЙНА ТЕХНОЛОГІЯ УПРАВЛІННЯ ПЕРСОНАЛОМ В ПЕРІОД КРИЗОВИХ ЯВИЩ}

CHOПEHKO Г. В., аспірант, Донецький державний університет управління

\section{WELL-BEING AS AN ADAPTATION TECHNIQUE FOR MANAGING HUMAN RESOURCES IN TIMES OF CRISIS}

\author{
SNOPENKO H. \\ Post-graduate Student, \\ Donetsk State University of \\ Management
}

У статті проаналізовано вплив розвитку технологій на добробут персоналу підприємств і визначено, що розмиті межі між роботою та домашнім офісом збільшують кількість стресу і призводять до вигорання співробітників. Розглянуто сутність "Well-being» технології як одного із методів профілактики синдрому професійного вигорання. Визначено найбільш поширені програми забезпечення добробуту персоналу $і$ запропоновано при формуванні моделі управління персоналом використовувати модель PERLA.

Ключові слова: технології управління персоналом, Well-being, ефективність персоналу, добробут персоналу, вигорання персоналу, залученість персоналу, модель PERLA.

В статье проанализировано влияние развития технологий на благосостояние персонала предприятий и определено, что размытые границы между работой и домашним офисом увеличивают стресс и приводят к выгоранию сотрудников. Рассмотрена сущность «well- 
being» технологии как одного из методов профилактики синдрома профессионального выгорания. Определены наиболее распространенные программы обеспечения благосостояния персонала и предложено при формировании модели управления персоналом использовать модель PERLA.

Ключевые слова: технологии управления персоналом, Wellbeing, эффективность персонала, благосостояние персонала, выгорание персонала, вовлеченность персонала, модель PERLA.

The article analyses the impact of technology development on the well-being of the workforce. It identifies that blurring boundaries between work and home office increases stress and leads to employee burnout. The article also describes the essence of well-being technology as a method to prevent the burnout syndrome. This article describes the most widespread welfare programmes and proposes using the PERLA model in shaping the HR model.

Key words: HR technologies, Well-being, staff efficiency, personnel well-being, staff burnout, staff involvement, PERLA model.

Постановка проблеми. Однією 3 найважливіших сучасних тенденцій в управлінні персоналом підприємств вважається зміна поглядів на людський ресурс. Показником ефективності успішних компаній стає вміння застосовувати методичний інструментарій для роботи 3 кадрами, тримати баланс між технократичним та гуманістичним підходами. Суть змін останніх десятиліть полягає у поступовому зміщенні акцентів у бік комплексного підходу до адміністративних завдань, який базується на довготривалому розвитку кадрового потенціалу та підвищенні якості персоналу. Спостерігаючи за динамікою науково-технічного прогресу, вивчаючи історію найбільших світових корпорацій, можна зробити закономірний висновок: необхідною умовою успішності будь-якої компанії $\epsilon$ сукупність ефективного кадрового менеджменту та використання сучасних технологій та методів.

Серед актуальних тенденцій у сфері управління персоналом можна виділити: поступове зростання інвестицій у кадровий ресурс поряд 3 капіталовкладеннями у технології; зростання значення комунікацій у сфері координації активності працівників; вирішення проблемних ситуацій разом із колективом [1].

Зауважимо, що за важливістю HR-тенденцій згідно зі звітом компанії Deloitte [2] добробут персоналу стоїть на першому місці. Так, 80\% респондентів виділили добробут серед таких тенденцій як еволюція ролі HR, управління знаннями та планування персоналу, тобто благополуччя сьогодні $\epsilon$ головним пріоритетом, а людина $\epsilon$ центром усіх виробничих процесів.

Враховуючи вищезазначене, а також той факт, що пандемія COVID-19 поставила під загрозу громадське здоров'я та викликала економічні потрясіння у всьому світі, забезпечення фізичного, психічного та соціального здоров'я співробітників $€$ актуальною проблемою.

Аналіз останніх досліджень і публікацій. Дослідженням процесів, пов'язаних з професійним вигоранням співробітників підприємств присвячено праці таких науковців, як: Л. М. Карамушка, Г. В. Гнускіна, В.В. Лукьянов, Н. Е. Водопьянова, В. Е. Орел, С. А. Подсадной, Л. Н. Юрьева, С. А. Игумнов, $[3 ; 4 ; 5]$. Значний внесок в дослідження факторів впливу на добробут персоналу зробили закордонні вчені: Том Рат, Джим Картер [6] та М. Селігман [7]. Однак, питання розробки системного підходу, який дозволить організаціям підвищити добробут, 
залученість та ефективність найманого персоналу, потребує всебічного дослідження в контексті розвитку адаптаційних HRтехнологій.

Метою статті $€$ актуалізація інформації та огляд технології Wellbeing, як ефективного інструменту управління персоналом в умовах кризових явищ.

Виклад основного матеріалу дослідження. Якщо до пандемії причиною професійного вигорання частіше ставали напружена обстановка в колективі, неоптимальне робоче середовище, невідповідність особистісних якостей займаній посаді або професія, пов'язана 3 щоденною високою відповідальністю та ризиками, то 3 квітня 2020 року причинами вигоряння та падіння ефективності все частіше стають:

- зруйнована комунікація між співробітниками та відділами;

- різні фактори, що відволікають в умовах «домашнього офісу»;

- зникнення кордонів між робочим та особистим часом.

Майже кожен п'ятий респондент глобального опитування Microsoft відзначає, що роботодавець не піклується про баланс між роботою та життям співробітників. 54\% опитаних почуваються перевтомленими. 39\% почуваються виснаженими.

Цифрова інтенсивність робочих днів значно зросла, середня кількість онлайн-зустрічей та чатів 3 початку пандемії зростає постійно. Зокрема, якщо порівняти тенденції співпраці в Microsoft 365 з лютого 2020 року по лютий 2021 року, то можна побачити наступне:

- час, проведений на зустрічах Microsoft Teams, збільшився у 2,5 рази у всьому світі;

- середня тривалість зустрічі команд стала на 10 хвилин довшою - з 35 до 45 хвилин за рік;

- середній користувач Teams надсилає на 45\% більше повідомлень на тиждень;

- продовжує зростати кількість повідомлень поза робочим часом.

Цей шквал комунікацій $€$ неструктурованим i, в основному, проходить не заплановано -62\% дзвінків та зустрічей команд відбуваються не за графіком. Працівники відчувають певний тиск: незважаючи на перевантаження, 50\% людей відповідають на повідомлення протягом п'яти хвилин або менше. Це доводить, що напруженість робочого дня і очікування від співробітників значно зросли [8].

Таким чином, з одного боку, комп'ютерні технології стали життєво важливим засобом, що дозволяють персоналу підприємства залишатися на зв'язку 24/7, з іншого боку, розмиті межі між роботою та домашнім офісом збільшують кількість стресу і призводять до вигорання співробітників. Отже, цифровізація та розвиток сучасних комп'ютерних технологій мають як позитивний, так і негативний вплив на добробут співробітників (рис. 1, рис. 2): найбільшим позитивним аспектом використання технологій $є$ можливість працювати в гнучкому форматі, а найбільшим викликом використання технологій $\epsilon$ неможливість розділити роботу та особисте життя. 


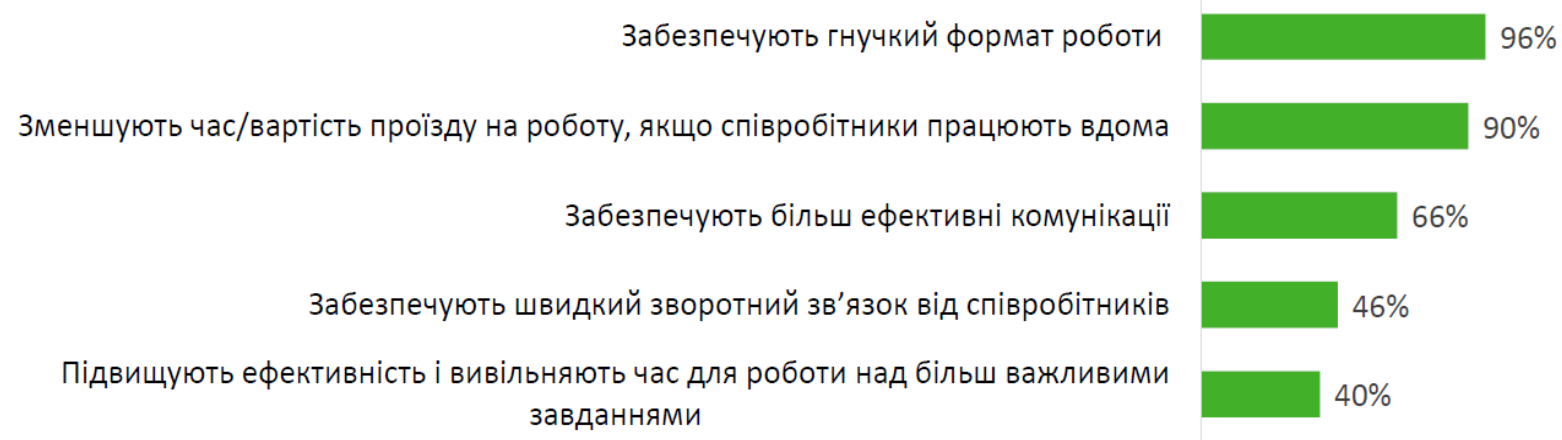

Рис. 1. Позитивний вплив технологій на добробут співробітників [9]

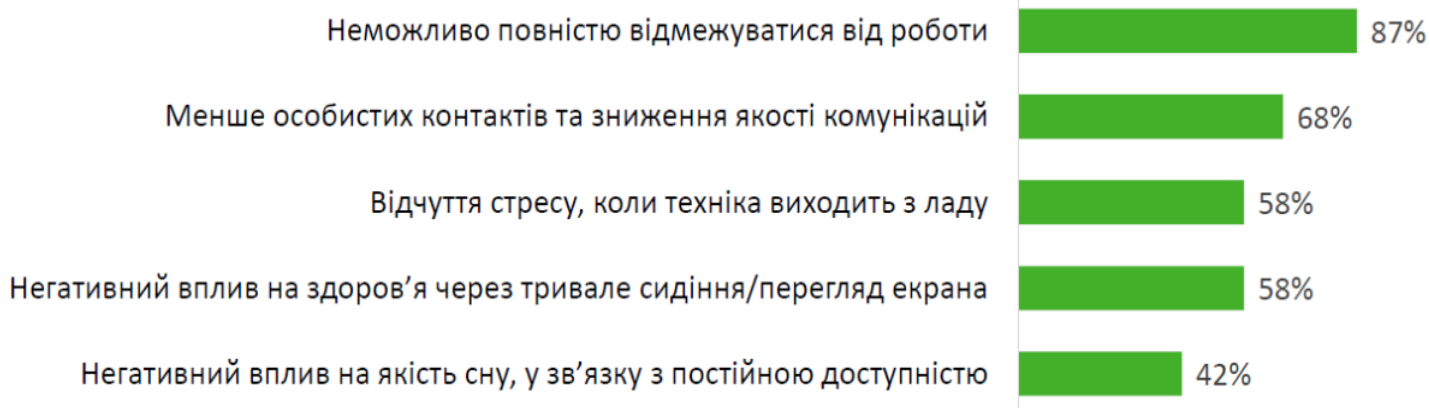

Рис. 2. Негативний вплив технологій на добробут співробітників [9]

Звіт 2020 року від компанії CIPD доводить, що співробітники по всьому світу не здатні знаходити компроміс між роботою та життям, що негативно впливає на здоров'я. 3'явилися нові поняття:

- абсентеїзм - вимушена відсутність на робочому місці через стрес та вигоряння (показник підвищився на 37\% за 2020 рік);

- презентеїзм - затримки на робочому місці навіть після закінчення робочого часу, при цьому часто без ефективного виконання завдань або за поганого самопочуття (на 89\% вище, ніж у 2019) [10].

Очевидно, що співробітник, який має проблеми зі здоров'ям, професійну стагнацію та високий рівень стресу схильний демонструвати низькі показники праці. Наслідки вигорання потенційно дуже серйозні для працівників, їх клієнтів та організацій, з якими вони взаємодіють. Але, згідно дослідженням К. Маслач і С. Джексон [11] не логічно вважати вигорання ознакою психологічної нестійкості конкретної людини або її невміння справлятися 3 труднощами; вигорання - проблема не співробітника, а роботодавця. Воно відбувається там, де виникає непорозуміння між керівництвом компанії та персоналом хоча 6 в одній із наступних областей: обсяг контролю, справедливість відносин, почуття спільності, рівень робочого навантаження, розподіл заохочень, цінності організації. Найвірніше рішення - у разі виникнення надзвичайних ситуацій на зразок нинішньої пандемії - підтримувати людей, а в майбутньому покращувати робочу атмосферу, забезпечивши співробітникам ефективний та комфортний баланс роботи та особистого життя. 
Основна помилка в оцінці вигорання персоналу - використання одного-двох показників. Некоректний підхід - запитати людину: «Чи нема в тебе випадково вигорання?». Такий підхід не дає жодної інформації про причини проблем та методи їх вирішення.

Для оцінки професійного вигорання у сфері соціальних послуг, освіти, бізнесу та державного управління, i розуміння природи емоційного вигорання співробітника доцільно використовувати опитувач вигорання Maslach Burnout Inventory (MBI) - це дослідження з 22 пунктів, що охоплює 3 області:

- емоційне виснаження - вимірює почуття перевтоми та виснаження від роботи;

- деперсоналізація - вимірює байдужість чи негативне ставлення до роботи;

- професійна ефективність (почуття власної гідності) - вимірює задоволеність минулими та справжніми досягненнями, а також однозначно оцінює очікування людини щодо постійної ефективності на роботі [12].

Кожна підшкала включає кілька питань з можливістю вибору наступної відповіді: ніколи, кілька разів на рік або рідше, раз на місяць або рідше, кілька разів на місяць, один раз на тиждень, кілька разів на тиждень або щодня.

Організації часто намагаються виміряти вигорання персоналу за допомогою щорічного опитування про стан здоров'я MBI, проте цей метод теж має кілька важливих обмежень. По-перше, під час такого опитування оцінюються лише пасивні форми вигорання та ігноруються його активніші форми. По-друге, таке опитування дає лише знімок поточної картини і часто не збігається за часом з найвищою точкою вигорання співробітника. По-третє, співробітники, які перебувають у стані вигорання, часто взагалі не заповнюють опитувальники [13].

Сьогодні, як ніколи раніше, люди розмірковують над своїм життєвим вибором, здоров'ям та цінностями та шукають відповідальних роботодавців, які відповідають їх запитам чи уявленням. Якщо співробітники задоволені своїм роботодавцем, це створює міцну основу для довгострокового процвітаючого бізнесу.

Гармонійне співіснування ключових елементів життєдіяльності людини, таких як здоров'я, професійна реалізація, фінансова стабільність, соціальні зв'язки та сприятливе середовище формують стан благополуччя, що знаходить своє відображення у концепції «wellbeing».

Well-being програма в компанії - це сучасний напрямок у сфері утримання кадрів, покликаний підвищити рівень благополуччя співробітників, а також залучення до робочого процесу. Такого висновку за останні десять років дійшли найбільші мультинаціональні корпорації, тим самим започаткувавши трансформацію поглядів на ефективність персоналу.

Well-being як комплексний підхід, що включає не тільки фізичний стан, а й інші аспекти, з'явився в 2010 році після виходу дослідження «Well-being: The Five Essential Elements»[6]. Том Рат та Джим Картер виділяють п'ять основних елементів добробуту людини: кар'єра, здоров'я, фінанси, соціальні зв'язки, суспільні зв'язки, хоча автор вважає, що в період кризових явищ також доцільно оцінювати і психологічну стійкість співробітників (табл. 1). 
Таблиця 1

Компоненти благополуччя співробітників

\begin{tabular}{|c|c|}
\hline $\begin{array}{l}\text { Кар'єрна } \\
\text { самореалізація }\end{array}$ & $\begin{array}{l}\text { Мотивація, самосвідомість, цілепокладання, } \\
\text { продуктивність, система цінностей. }\end{array}$ \\
\hline $\begin{array}{l}\text { Фінансова } \\
\text { ефективність }\end{array}$ & $\begin{array}{l}\text { Планування майбутнього, страхування життя, } \\
\text { бюджетування, заощадження, пенсія. }\end{array}$ \\
\hline Фізичне здоров'я & $\begin{array}{l}\text { Робоче середовище, спортивне тренування, } \\
\text { харчування, водний баланс, сон. }\end{array}$ \\
\hline $\begin{array}{l}\text { Психологічна } \\
\text { стійкість }\end{array}$ & $\begin{array}{l}\text { Ментальне здоров'я, уважність, впевненість у собі, } \\
\text { встановлення на розвиток, управління стресостійкістю. }\end{array}$ \\
\hline $\begin{array}{l}\text { Соціальна } \\
\text { затребуваність }\end{array}$ & $\begin{array}{l}\text { Відносини, підтримка керівника, підтримка колег, } \\
\text { емоційний інтелект. }\end{array}$ \\
\hline
\end{tabular}

На основі цієї загальної моделі доктор Мартін Селігман, президент Американської психологічної асоціації, у 2011 році розробив свою модель - PERMA, яка активно використовується в якості основи для корпоративних програм добробуту в багатьох закордонних компаніях і може бути залучена в практику українського менеджменту. Модель PERMA охоплює наступні показники:

- Positive Emotions - позитивні емоції, гарні враження;

- Engagement - залучення до того, що робиш щодня;

- Relationships - відносини з оточуючими;

- Meaning - мета та насиченість існування;

- Accomplishment - досягнення [7].

У той час як $66 \%$ людей досягають успіху хоча 6 в одній 3 цих областей, тільки 7\% досягають успіху в усіх п'яти, тому дослідники компанії CIPD визначають концепцію well-being як «створення середовища для досягнення задоволеності, яке дозволяє співробітнику процвітати та повністю розкривати свій потенціал для себе та своїй організації». При цьому підтримкою добробуту потрібно займатися постійно, від процесу найму до останнього робочого дня $\mathrm{i}$ вибудовувати ії так, щоби знайшовся баланс між потребами співробітника та потребами компанії. Згідно з дослідженням CIPD [10] well-being програма покращує показники успішності бізнесу у шість разів.

На сьогодні технологія "well-being» знаходиться в процесі свого динамічного розвитку і з кожним роком все більша частка українських компаній стають прихильниками концепції, активно ії̈ практикуючи. Так, у світлі останніх подій, пов'язаних з пандемією COVID-19, загальний запит на непідробне благополуччя зріс багаторазово: $82 \%$ роботодавців адаптували програми забезпечення добробуту, зробивши фокус на ментальному здоров'ї персоналу, розширенні програм страхування, впровадженні різноманітних ініціатив для зменшення впливу віддаленої роботи на емоційний стан співробітників (рис. 3). Найбільш поширеними серед них $€$ проведення командних онлайн-зустрічей, тімбілдінгів та забезпечення комфортних умов віддаленої роботи. 


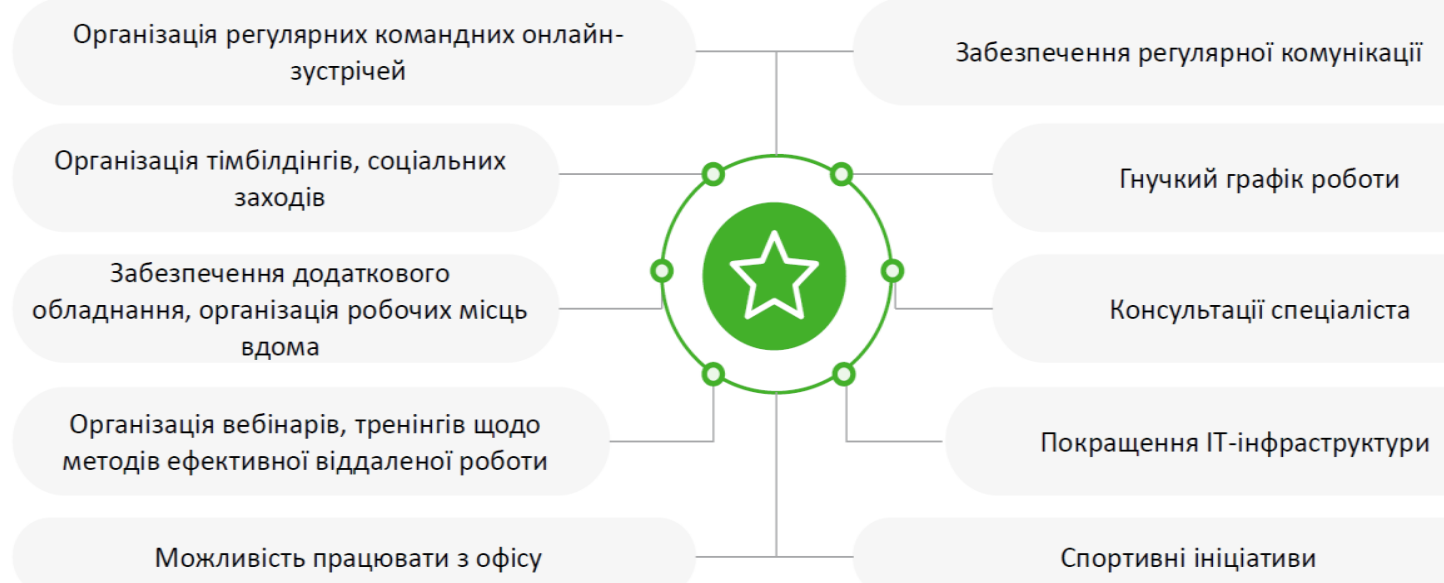

Індивідуальні зустрічі з HR та/або керівником

Рис. 3. Програми забезпечення добробуту персоналу [9]

Підсумуємо, що в центрі уваги менеджерів з персоналу мають бути оцінка добробуту людей в організації, а також прогноз майбутнього характеру взаємодії персоналу з організацією. Стратегія підвищення культури добробуту в компанії може включати наступні елементи:

- доступ до ліній психологічної підтримки;

- семінари та практики з питань психічного здоров'я: тренінги зі співробітниками, ігри та робота в групах;

- зворотний зв'язок та анкетування для оцінки рівня стресу;

- регулярні зустрічі 3 колективом в офісі та поза ним (зумконференції в умовах пандемії).

HR-менеджерам також доцільно використовувати автоматизовані системи, за допомогою яких можна:

- відстежити показник індивідуального настрою співробітника;

- планувати зустрічі 1-on-1 на регулярній основі, щоб мати можливість вислухати співробітника та його думки щодо проєкту, завдань, цілей, комунікації;

- полегшити рутинні процеси - наприклад, надати доступ до автоматичного обліку вихідних та відпускних днів, доступ до комунікації з іншими співробітниками та відділами;

- чітко планувати цілі та завдання за допомогою персональних OKR, щоб бачення про спільні плани у співробітника та менеджера збігалося;

- регулярно проводити оцінки 180 та 360, підлаштовувати їх під співробітників, відділи чи компанію загалом.

Висновки і перспективи подальших досліджень. Дослідження основних світових тенденцій управління персоналом дозволяють виділити добробут серед таких тенденцій як еволюція ролі HR, управління знаннями та планування персоналу, тобто благополуччя сьогодні $€$ головним пріоритетом, а людина $€$ центром усіх виробничих процесів.

Аналіз впливу розвитку технологій на добробут персоналу підприємств дозволив визначити, що розмиті межі між роботою та домашнім офісом збільшують кількість стресу, а проблеми та негативні явища, пов'язані з розповсюдженням коронавірусної інфекції призвели 
до збільшення випадків емоційного вигорання. Отже, сучасному менеджменту доцільно орієнтуватися на технології, які допомагають створити сприятливі умови для адаптації персоналу до кризових явищ. 3 метою вирішення проблеми професійного вигорання, актуалізовано сутність «well-being» технологіi, яка дозволить підвищити рівень добробуту та залученості співробітників до робочого процесу, навіть у період нестабільної ринкової ситуації. В статті визначено найбільш поширені програми забезпечення добробуту персоналу i запропоновано при формуванні моделі управління персоналом використовувати модель PERLA.

\section{Отримані результати}

представляється

доцільним використовувати для подальшого детального та системного вивчення впливу пандемії на зміни практик управління персоналом, формування нових моделей здорового робочого середовища i адаптації корпоративних стратегій управління персоналом під нього, що складає перспективи подальших досліджень.

\section{Література:}

1. Современные технологии управления персоналом. URL: https://www.hr-director.ru/article/63462-red-qqq-15-m4-sovremennyetehnologii-kontseptsii-upravleniya-personalom.

2. 2021 Deloitte global human capital trends. URL: www2.deloitte.com/content/dam/insights/us/articles/6935_2021-HCTrends/di_human-capital-trends.pdf.

3. Карамушка Л. М., Гнускіна Г. В. Психологія професійного вигорання підприємців: монографія. К: Логос, 2018. 198 с.

4. Технологія психологічної підготовки персоналу організацій до роботи в умовах соціально-економічних змін (на матеріалі освітніх організацій): навч. посіб. / за наук. ред. Л. М. Карамушки. К.: Наук. світ, 2008. 230 с.

5. Современные проблемы исследования синдрома выгорания у специалистов коммуникативных профессий: коллект. монография /под ред. В. В. Лукьянова, Н. Е. Водопьяновой, В. Е. Орла, С. А. Подсадного, Л. Н. Юрьевой, С. А. Игумнова. Курск: курский гос. ун-т., 2008. 336 с.

6. Исследование Microsoft: 7 изменений в работе, к которым должен приспособиться каждый руководитель. https://www.epravda.com.ua/rus/publications/2021/04/7/672716/.

7. Дослідження добробуту співробітників: визначення шляху до успіху. URL: https://www2.deloitte.com/ua/uk/pages/press-room/pressrelease/2021/well-being-survey.html.

8. Health and wellbeing at work 2021 URL: https://www.cipd.co.uk/Images/health-wellbeing-work-report2021_tcm18-93541.pdf.

9. Christina Maslach, Susan E. Jackson. The measurement of experienced burnout. Journal of occupational behavior. 1981. Vol. 2. P. 99-113.

10. Christina Maslach, Susan E. Jackson. Maslach Burnout Inventory (MBI). URL: https://www.mindgarden.com/117-maslachburnout-inventory-mbi\#horizontalTab1.

11. Осторожно, выгорание. URL: https://hbrrussia.ru/management/upravlenie-personalom/856506.

12.Tom Rath, Jim Harter. The Five Essentials Elements of Well-Being URL: ttps://www.gallup.com/workplace/237020/five-essentialelements.aspx. 
13. Perma theory of well-being. URL: https://ppc.sas.upenn.edu/learn-more/perma-theory-well-being-andperma-workshops.

References:

1. Sovremennye tekhnologii upravleniya personalom URL: https://www.hr-director.ru/article/63462-red-qqq-15-m4-sovremennyetehnologii-kontseptsii-upravleniya-personalom

2. 2021 Deloitte global human capital trends URL: www2.deloitte.com/content/dam/insights/us/articles/6935_2021-HCTrends/di_human-capital-trends.pdf

3. Kăramushka L. M., Ghnuskina Gh.V. Psykhologhija profesijnogho vyghorannja pidpryjemciv: monoghrafija. K: Loghos. 2018. $98 \mathrm{s.}$

4. Tekhnologhija psykhologhichnoji pidghotovky personalu orghanizacij do roboty $v$ umovakh socialjno-ekonomichnykh zmin (na materiali osvitnikh orghanizacij): navch. posib. Za nauk. red. L. M. Karamushky. K.: Nauk. Svit. 2008. 230 s.

5. Sovremennye problemy issledovaniya sindroma vygoraniya $u$ spetsialistov kommunikativnykh professiy: kollektivnaya monografiya pod red. V.V. Luk'yanova, N.E. Vodop'yanovoy, V.E. Orla, S.A. Podsadnogo, L.N. Yur'evoy, S.A. Igumnova. Kursk. gos. un-t. Kursk. 2008. $336 \mathrm{~s}$.

6. Issledovanie Microsoft: 7 izmeneniy $v$ rabote, $\mathrm{k}$ kotorym dolzhen prisposobit'sya kazhdyy rukovoditel' URL: https://www.epravda.com.ua/rus/publications/2021/04/7/672716/

7. Doslidzhennja dobrobutu spivrobitnykiv: vyznachennja shljakhu do uspikhu URL: https://www2.deloitte.com/ua/uk/pages/pressroom/press-release/2021/well-being-survey.html

8. Health and wellbeing at work 2021 URL: https://www.cipd.co.uk/Images/health-wellbeing-work-report-

2021_tcm18-93541.pdf

9. Christina Maslach, Susan E. Jackson (1981) The measurement of experienced burnout. Journal of occupational behavior. Vol. 2. 99-113

10. Christina Maslach, Susan E. Jackson. Maslach Burnout Inventory (MBI). URL: https://www.mindgarden.com/117-maslachburnout-inventory-mbi\#horizontalTab1

11. Ostorozhno, vygoranie URL: https://hbrrussia.ru/management/upravlenie-personalom/856506

12.Tom Rath, Jim Harter. The Five Essentials Elements of Well-Being URL: $\quad$ ttps://www.gallup.com/workplace/237020/five-essentialelements.aspx

13. Perma theory of well-being URL: https://ppc.sas.upenn.edu/learn-more/perma-theory-well-being-andperma-workshops

The COVID-19 pandemic proved the value of human capital. It is about the physical health of staff and the evolution of the employee's place and role in the organisation. The issues and negative phenomena mentioned above have a significant impact on the activities and functioning of companies, which is why in crisis conditions, it is relevant to rethink the role of personnel in the enterprise management system. Moreover, models and methods of anti-crisis personnel management 
using modern adaptation technologies have also a significant impact. The production of "surplus value", digitalisation and informatisation along with the "gig economy" require a highly skilled workforce. Hence, companies have to make increasing efforts to attract and retain the most talented and promising employees. The article analyses the impact of technology development on the well-being of the workforce. It identifies that blurring boundaries between work and home office increases stress and leads to employee burnout. In recent years the focus of Ukrainian companies, based on global experience, has shifted to investing in the welfare of employees, creating a favourable internal environment for staff and providing a competitive advantage in the labour market. The current research focuses on developing a systematic and fundamental approach that will enable organisations to address employee health risk management, reduce the costs associated with poor employee health, increase employee engagement and effectiveness, and attract potential recruits. Managing employee well-being is becoming a reality with corporate programmes and products. The article also describes the essence of well-being technology as a method to prevent burnout syndrome, which aims to increase employee well-being and involvement in the work process, and as a result, to improve staff performance, achieve strategic planning efficiency, economic stability and create a competitive business. The author identifies the most common employee well-being and engagement programmes. This article describes the most widespread welfare programmes and proposes using the PERLA model in shaping the HR model. 